Article

\title{
RAT (Rattus rattus diardii L.) REPELLENT MADE OF SOURSOP (Annona muricata L.) LEAVES EXTRACT
}

\author{
Meida Dewanti ${ }^{1, a}$, Fatona Wahyu Pandi Hastuti ${ }^{1, b}$, Titis Dhian Novita ${ }^{3}$, Rizqi Triananda ${ }^{4}$, \\ Arif Jumari ${ }^{5}$
}

Chemical Engineering Undergraduate Study Program, Engineering Faculty, Surakarta Sebelas Maret University

Ir. Sutami Street No. 36 A Kentingan Surakarta 57126

E-mail: ${ }^{a}$ meimeidewanti@gmail.com, ${ }^{b}$ fatwphh@gmail.com

\begin{abstract}
House rat (Rattus rattus) is a rodent that can damage any objects at home and leave manure there by resulting in bad odor and rat also becomes a host of some disease vectors. The use of plant repellent is one alternative control utilizing rat's olfactory sense. The Soursop (Annona muricata $L$ ) is a plant with very stinking aroma and very disliked by rat, thereby can be used as plant repellent. The aim of the research was to extract the soursop leaves and to use its extract as the active material of rat repellent. The methods employed in preparing of rat repellent from soursop leaves were grinding and maceration extraction using two different solvent, water and ethanol $96 \mathrm{wt} \%$. The extract was then examined as an active material of rat repellent. The examination was conducted by adding the soursop extract to the rat food. The results showed that the loss of rat food with repellent made of grinded soursop leaves was $1 \%$, while with repellent made of combined grinded soursop leaves and ethanol was $2.48 \%$. The loss of rat food with repellent made of water solvent soursop exstract leaves was $64.5 \%$, and that using repellent made of ethanol solvent soursop was $16.67 \%$. So, the utilization of soursop leaves as rat repellent was expected to reduce rat population in the people's houses.
\end{abstract}

Keywords: soursop, repellent, extraction, loss of rat food

EQUILIBRIUM Volume 2 No.2 July 2018

Online at http://equilibrium.ft.uns.ac.id 


\section{INTRODUCTION}

House rat (Rattus rattus) is a rodent with long tail and good climbing and jumping skills found easily in houses. This animal is nocturnal and omnivore. Rat often eats cloth and damages other objects such as cable network at home. Rat not only damages various objects at home but also often leaves manure resulting in bad odor. Rat can also be the host of disease vectors ${ }^{1}$.

Rat population control is highly emphasized on to mitigate the loss generated by rat pest ${ }^{2}$. Currently, house rat control is conducted by, among others, using trap and rodenticide. The use of trap as the rat controlling technique in settlement is a safe and economic method, because it can be used several times. However, the used trap should be cleaned thereby not leaving rat's urine or manure potentially making it trap-wary. Meanwhile, rodenticide is a material containing poisonous chemical compound used to kill rodent such as rat, by poisoning its feed ${ }^{3}$. However this method is not effective and not environmentfriendly because it will die near the place where the poison is put and the rat carcass will result in bad odor harmful to human life comfort.

Considering the disadvantage of rat trap and rodenticide use, a more effective method is required, that is using rat repellent ${ }^{4}$. Repellent is a compound acting locally or in certain distance capable of preventing organism to approach. Plant repellent materials with ability of repelling rat are yellow sandalwood (cendana) oil, patchouli (nilam), and fragrant root (akar wang $)^{5}$, morinda, soursop leaves, bintaro, and berenuk ${ }^{6}$.

Soursop (Annona muricata L.) leaves is a plant with stinking aroma disliked by rat. It can be used as plant rat repellent utilizing the rat's strong smelling sense ${ }^{6}$. The directly use of soursop leaves as rat's repellent is less effective because in short period of time, soursop leaves will be dry; thus a processing using certain method is required to make soursop leaves aroma long-standing. Considering the losses generated by rat pest and the potency of soursop leaves, the use of soursop leaves can be optimized more as the active material for preparing rat repellent. The aim of the research was to extract the soursop leaves and to use its extract as the active material of rat repellent.

\section{METHOD}

The tools used in this experiment were stone grinder, balance, beaker glass, graduated cylinder, and spoon. The materials used were soursop leaves and two kinds of solvent, water and ethanol $96 \mathrm{wt} \%$, used for maceration extraction.

The methods employed in preparing rat repellent from soursop leaves were soursop leaves grinding and maceration extraction. For soursop leaves grinding, soursop leaves was grinded using stone grinder and then added with ethanol in ratio of 1:1. In the maceration extraction method, soursop leaves were grinded using stone grinder and then put into a contained, added with ethanol in ratio of 1:2 and closed tightly and left for 2 days. Having been extracted for 2 days, soursop leaves was extracted and taken for its filtrate.

The sample resulted from soursop leaves grinding was tested using 2 types of sample: The grinded soursop leaves and the combined grinded soursop and ethanol $96 \%$. The test on the sample resulting from soursop leaves maceration extraction, 2 types of sample were used: filtrate extracted from soursop leaves using water and filtrate extracted from soursop leaves using ethanol $96 \%$. Each of test result from soursop leaves grinding and maceration extraction methods was compared with control test result.

The test was conducted by preparing stall arena. The stall was divided into 2 rooms, each of which is separated with chamber with a door as the rat's means of moving from one room to another. The tested rat was adapted first in the stall for 2 days. During adaptation, feed control test was conducted to be compared with feed test result given sample repellent. After 2-day adaptation, the rat food with equal weight were administered to each of stall rooms with rat repellent being administered to one of rooms; then the food weight was weighed every 1 hour for 5 hours to find out the loss of rat food indicating the rat's opportunity of entering into the room given repellant. 


\section{RESULT AND DISCUSSION}

The test on soursop leaves as rat repellent used 2 types of sample repellent: grinded soursop leaves and soursop leaves extract. The result of test on rat repellent made of grinded soursop leaves is presented in Table 1 and that made of soursop leaves extract is presented in Table 2.

Table 1. The comparison of the loss of rat food between Control Test and Sample Test of Repellent Made of Grinded Soursop Leaves.

\begin{tabular}{cccc}
\hline Hour & Sample I $(\%)^{*}$ & Sample II $(\%)^{* *}$ & Sample III $(\%)^{* * *}$ \\
\hline 0 & 0 & 0 & 0 \\
1 & 14.83 & 0 & 0 \\
2 & 20.10 & 0 & 0.83 \\
3 & 23.44 & 0 & 0.83 \\
4 & 24.40 & 1 & 0.83 \\
5 & 32.30 & 1 & 2.48 \\
\hline
\end{tabular}

* Sample I was rat food with no repellent (control test)

** Sample II was rat food with repellent made of grinded soursop leaves.

*** Sample III was rat food with repellent made of combined grinded soursop leaves and ethanol $96 \%$

From Table 1, it can be seen that control test (without repellent) during 5-hour testing, the loss of rat food always increased significantly compared with the sample with grinded soursop leaves and the sample with combined grinded soursop leaves and ethanol 96\%. It indicated that rat repellent made of soursop leaves impacts on rat expulsion. The loss of rat food with repellent made of grinded soursop leaves was less than the loss of rat food with repellent made of mixed grinded soursop leaves and ethanol $96 \%$. It mean that repellant made of grinded soursop leaves had more impacts on rat expulsion compared with repellent made of mixed grinded soursop leaves and ethanol 96\%.

Table 2. The comparison of the loss of rat food between between Control Test and Sample Test of Repellent made of Soursop Leaves Extract

\begin{tabular}{cccc}
\hline Hour & Sample I $(\%)^{*}$ & Sample II $(\%)^{* *}$ & Sample III $(\%)^{* * *}$ \\
\hline 0 & 0 & 0 & 0 \\
1 & 14.83 & 16 & 6.2 \\
2 & 20.10 & 41.5 & 6.2 \\
3 & 23.44 & 53.5 & 6.6 \\
4 & 24.40 & 60.5 & 7.1 \\
5 & 32.30 & 64.5 & 7.2 \\
\hline
\end{tabular}

* Sample I was rat food with no repellent (control test)

** Sample II was rat food with repellent made of water solvent Extract

*** Sample III was rat food with repellent made of ethanol solvent Extract

From Table 2, it can be seen that the examination of rat repellent made of water solvent soursop leaves extract, the loss of rat food increased significantly compared with control test (without repellent treatment) because the exstract was actually only water and no compound affects the rat's smelling sense and the rat liked more the moist and watery places. Meanwhile, the rat food given with repellent made of ethanol solvent extract showed the smallest of the loss of rat food that mean it had that high impacts on rat expulsion.

The comparison of result presented in Table 1 and Table 2 showed the use of rat repellent made of grinded soursop leaves more effectively expels rat but the repellent lasts for 1 day only, as it will be dry after one day and no longer resulting in stinking aroma of soursop leaves. Meanwhile, the use of rat repellent made of ethanol solvent soursop leaves extract can be stored for 30 days although its rat expulsion is less lower than the one made of grinded soursop leaves.

The use of plant rat repellent as the rat controlling method is relatively safer as it is made of natural material, environment-friendly and not poisonous. Rat repellent expels rat only by utilizing rat's dislike against soursop leaves' stinking aroma, so that rat will go away itself and will not die leaving carcass in houses. However, in the effectiveness of rat expulsion, the chemicals playing active role in affecting the

RAT (Rattus rattus diardii L.) REPELLENT MADE OF SOURSOP (Annona muricata L.) LEAVES EXTRACT

(Meida Dewanti, Fatona Wahyu Pandi Hastuti, Titis Dhian Novita, Rizqi Triananda, Arif Jumari) 
rat's smelling sense and the rat's smelling radius have not been known yet. Thus, further studies should be conducted to find out the chemicals contained in soursop leaves and the radius of rat's smelling sense to plant rat repellant made of soursop leaves.

\section{CONCLUSION}

The conclusion of the research were that rat repellent could be made from soursop leaves. The rat repellent made from grinded soursop leaves had higher impact on rat expulsion but very short life time. The rat repellent made of ethanol solvent soursop leaves has less lower impact on rat expulsion but it had long life time.

\section{REFERENCES}

1. Meehan AP, "Rat and Mice, Their Biology and Control", East Griendstead (GB), Rentokil, 1984

2. Grainge, M. and S. Ahmed, "Handbook of Plants and Pest Control Properties"New York, John Wiley and Sons, 1998

3. Ramadani, Sonya Suci, “" Uji Rodentisida, Perangkap, Dan Repelen, Serta Persepsi Masyarakat Terhadap Tikus Permukiman Di Cibinong, Bogor”, Institut Pertanian Bogor, Bogor(ID), 2016

4. Amelia TS, "Pengujian Repelensi dari empat jenis tanaman terhadap tikus rumah (Rattus rattus iardii L)", Institut Pertanian Bogor, Bogor (ID), 2015

5. Kardinan, Agus, "Pestisida Nabati: Ramuan dan Aplikasi", Jakarta, Penebar Swadaya, 2004

6. Natawigena WD, Bari IN, Susanto A, "Repelensi minyak cendana, nilam, dan akar wangi terhadap tikus sawah (Rattus argentiventer Robb. \& Kloss.) di laboratorium”, Jurnal Bionatura. 1(1):1-10, 2003 